\title{
Basel II - Benefits for Developing Countries?
}

\author{
Martina Metzger*
}

\begin{abstract}
The major target of the new capital accord which was adopted in 2004 and is implemented not before 2007 is to prevent bad banking by introducing more risk-sensitive capital requirements. This paper analyses the impacts of Basel II on developing countries which have been most strongly affected by bad banking. The paper identifies structural, price and displacement effects of Basel II which will change international lending to developing countries. While lower-rated developing countries' access to international capital markets will be restrained even further, an accumulation of foreign debt by higher-rated developing countries will be encouraged. Moreover, the new capital accord induces structural and displacement effects on credit markets in developing countries themselves. Due to the use of different approaches toward the measurement of risk, domestic banks will loose competitiveness against subsidiaries of internationally operating banks. For the former this will result in an increased vulnerability to shocks and financial crises.
\end{abstract}

JEL classifications: $E_{44}, F_{34}, G_{15}, G_{2} 8$

Keywords: Basel II, currency crises, bad banking, herding behaviour

* $\quad$ BIF, Berliner Institut für Finanzmarktforschung. This paper was presented at the $14^{\text {th }}$ World Congress of the International Economic Association in Marrakech (Morocco) in September 2005 . Financial support by the German Research Foundation is gratefully acknowledged. Special thanks go to the participants of the developing countries' panel and two anonymous referees for valuable comments. The usual disclaimers apply.

Correspondence address:

Dr. Martina Metzger, BIF, Berliner Institut für Finanzmarktforschung, Samariterstr. 28, IO247 Berlin, Germany, e-Mail: martina.metzger@bif-berlin.de

Received 9 May 2005, accepted 8 February 2006

(C) INTERVENTION. Journal of Economics, Vol. 3 (2006), No. 1, pp. 131-150 


\section{Introduction}

The purpose of this paper is to analyse the impacts of Basel II on developing countries. The currency crises which occurred rather frequently during the 1990s (Mexico 1994, Southeast Asia 1997, Russia 1998, Brazil 1998-1999 and finally Argentina 200I-2003) gave the major impulse to revise the old capital accord of 1988 . Especially the Asian crisis turned out to be a watershed with regard both to the volume of financial funds provided during the crisis by the international community and to the involvement of private actors in the outbreak and course of the crisis, namely foreign and domestic banks. The major, if not sole, factor causing the Asian crises is said to be bad banking (Metzger 200I, Krugman 1998a). Excessive credit expansion both by international lenders and domestic banks financed a credit boom which gave rise to a full-blown bubble. After the bubble burst in 1997, sparking off the crisis, the ensuing credit crunch was aggravated by the refusal of international private creditors to roll-over short-term credits, and by a currency mismatch between assets and liabilities in the balance sheets of Asian domestic banks. As Krugman puts it: "The crisis, in short, was a punishment for Asian sins, even if the punishment was disproportionate to the crime." (1998b: 3 )

As early as 1999, the Basel Committee on Banking Supervision at the Bank for International Settlements launched an initiative with the objective of redesigning international banking rules. Its approach would achieve the opposite of Krugman's assessment of the late crisis - a nno sins, no punishment situation. The new design aimed to prevent bad banking by introducing more risk-sensitive standards for internationally operating banks. Since then, the various suggestions have been drawn up in three so-called "consultative proposals" (CP) dating from 1999, 200I, and 2003. After repeated postponements the new capital accord was adopted in June 2004 and is to be implemented world-wide not before 2007 .

Although the target group of Basel II are internationally operating banks, it is developing countries which have carried and still carry the main burden of the above-mentioned currency crises in financial, economic and social terms. Are developing countries therefore the main beneficiaries of the new capital accord?

In the first instance, a brief overview of Basel I will be given. This will be followed by a discussion of the main changes under Basel II focusing on Pillar One, which deals with systemic failures of banking systems. The forth section will highlight the impacts of Basel II on international lending from the perspective of developing countries. The fifth section will draw on the impacts of Basel II on credit markets in the developing countries themselves. Finally, the main findings will be summarised in a conclusion.

\section{Basel I}

The old capital accord, adopted in 1988, for the first time introduced an internationally compulsory standard for internationally operating banks. The standard itself is relatively simple, as the risk weights and the thereof derived capital requirements are allocated ac- 
cording to only three distinctive features, namely membership in the OECD, maturity of claims, and finally, debtor category as can be seen in tables I and 2.

Table I: Risk Weights of Claims (Basel I) in \%

\begin{tabular}{lcc}
\hline & OECD & Non-OECD \\
\hline Sovereigns & 0 & 100 \\
Banks & & \\
-12 months and more & 20 & 100 \\
- up to 12 months & 20 & 20 \\
Corporates & 100 & 100 \\
\hline
\end{tabular}

Source: Basel Committee 1988

Excluding short-term claims on banks, all claims on non-OECD debtors receive a risk weight of Ioo per cent, which requires a minimum capital of eight per cent of the credit volume. Short-term ‘ means a period up to twelve months; the risk weight for such claims on banks is considered 20 per cent, which translates into a capital charge of I.6 per cent with regard to the credit volume. Claims on banks from OECD countries show a risk weight of 20 per cent independent of their maturity, whereas corporate entities in OECD countries share the uniform risk weight of Ioo per cent with their counterparts in non-OECD countries. The risk weight for sovereigns also depends on membership in the OECD. OECD countries get favourable treatment in that they are automatically assigned to a risk weight category of zero per cent, which implies an absolute certainty of repayment and the impossibility of default.

\begin{tabular}{|c|c|c|}
\hline & OECD & Non-OECD \\
\hline Sovereigns & 0 & 8 \\
\hline \multicolumn{3}{|l|}{ Banks } \\
\hline-12 months and more & 1.6 & 8 \\
\hline - up to 12 months & 1.6 & 1.6 \\
\hline Corporates & 8 & 8 \\
\hline
\end{tabular}

Source: Basel Committee 1988

Developing countries were not at the table when Basel I was drafted behind closed doors. The originators of Basel I were the governors of the Gio central banks, whose concern was "that the capital of the world's major banks had become dangerously low after persistent erosion through competition. $\aleph^{\mathrm{I}}$ The debt crisis of the $1980 \mathrm{os}$ and the defaulted sovereign

I Secretariat of the Basel Committee (200I), Annex 3, p. II. See also United Nations Centre on Transnational Corporations (1991: 80-92). 
debtors in developing countries could nonetheless claim parentage of this old capital accord. While western European banks quickly increased their reserves, agreed upon partial debt relief and in general executed a broad withdrawal from developing countries, US banks failed to raise reserves adequately and were very reluctant to grant even partial debt relief. Hence, US banks themselves seemed to be at risk to default due to the accumulation of non-performing loans in their portfolios.

"If action is not taken, the international debt crisis will become primarily a United States problem owing to the increasing concentration of debt in the accounts of the big United States banks." (United Nations Centre on Transnational Corporations I99I: 9I)

The result of the divergent strategies of international banks vis-à-vis the debt crisis was that those internationally operating banks which did not participate in herding behaviour were ultimately left with the worst portfolios. This fact was a major impetus for the Gio governors to implement Basel I as a measure of protection for internationally operating banks which failed to increase their reserves and to withdraw from risky market segments in time.

"In fact, the same international agreement on capital adequacy [Basel I, MM] stipulates that United States banks will need to have capital (equity and long-term debt) equal to 8 per cent of /risk-adjusted assets (which include off-balance sheet items) by the end of 1992, something which will be more difficult for the big United States banks than for others, since they are the most at risk with regard to sovereign debt defaults; Euromoney suggested that the principal effect would be to force the major United States banks to slash assets and divest." (United Nations Centre on Transnational Corporations I991: 88, emphasis not in the original)

A further step was the introduction of a market risk, which was incorporated into Basel I as a reaction to the Mexican crisis of 1994 and came into effect in 1997 (Basel Committee 1995, 1996). A market risk is defined as the loss of banks due to net open foreign positions in the course of an unfavourable - meaning unexpected negative - trend in market prices. Since the end of 1994 the net open foreign positions and the exchange rate risks derived from them also require a uniform capital charge of eight per cent or - if existing - capital charges based on risk weights measured by internal risk estimation systems (Basel Committee 1994).

\section{Basel II}

Contrary to the single pillar of Basel I, which consists of minimum capital requirements, the new accord is based on three pillars. The main changes in Basel II with regard to Basel I refer to more risk-sensitive capital requirements (first pillar), a strengthening of the supervisory review process (second pillar), and increased publication commitments by banks to 
enforce market discipline (third pillar). According to the second pillar, national supervisory authorities are supposed to ensure both the adequacy of minimum capital requirements relative to the risk profile of a particular bank and the use of sound internal risk estimation and assessment processes. To fulfil this task, national supervisory authorities are assigned far-reaching rights, including the right to revoke bank operating permits and the closure of banks in case of a negative evaluation in the course of the supervisory review process. Moreover, the third pillar makes banks subject to disclosure of a wide range of information, including their risk assessment methods and capital calculations, to force them to unveil to market agents their risk profiles and the adequacy of their capital requirements. Both the second and third pillars aim to enable supervisory authorities and market participants to impose sanctions on a single bank in case of regulatory or market failure.

However, it is the first pillar that sets incentives to change credit expansion mechanisms by banks in order to prevent the kind of systemic failure of banking systems which had been revealed during the above-mentioned currency crises in developing countries. The capital requirements of the first pillar, more risk-sensitive than Basel I, are to be enforced by three changes: differentiated capital requirements (3.I), different approaches to measuring credit risk (3.2), and the introduction of operational risk (3.3). ${ }^{2}$

\section{I Differentiated Capital Requirements}

Under Basel II, capital requirements are intended to adequately reflect credit risk. Hence, the new capital accord is supposed to make credit supply more risk-sensitive than it was under the old arrangement. The minimum capital requirements of Basel II are based on two of the three features already familiar from Basel I, namely debtor categories and maturity. However, under Basel II, a differentiation in the capital requirements is not only possible between different debtor categories, but also between individual debtors within the same category. The main instrument for enforcing greater risk-sensitivity in credit expansion is the assessment of an individual debtor, be it a sovereign, a bank or a corporate. Claims by banks are assigned to risk weights - and hence to minimum capital requirements - according to ratings. Different borrowers imply different ratings, or borrower grades, which is reflected in different risk weights and therefore in different capital requirements.

As is shown in tables 3 and 4 (page 136), the preferential treatment of OECD sovereigns and banks will cease to exist with the implementation of Basel II. With the admission of several emerging market economies to the OECD, the old capital accord is no longer up to date. Of the current thirty members of the OECD, seven represent emerging market economies, of which all but Turkey became members during the I990s. Both Mexico and South Korea even obtained full membership in the OECD only a few months prior to the outbreak of their respective crises. Membership in the OECD no longer ensures repayment with absolute certainty nor does it preclude default as is implicit in the risk weight of zero for sovereign OECD debtors under Basel I. Therefore, sovereign debtors

2 If not otherwise specified this paragraph refers to Basel Committee (2003a, 2005). 
Table 3: Risk Weights of Claims (Standardised Approach Basel II)

\begin{tabular}{lcccccc}
\hline & AAA to AA- & A+ to A- & BBB+ to BBB- & BB+ to B- & Below B- & Unrated \\
\hline Sovereign & $0 \%$ & $20 \%$ & $50 \%$ & $100 \%$ & $150 \%$ & $100 \%$ \\
Bank Option 1 & $20 \%$ & $50 \%$ & $100 \%$ & $100 \%$ & $150 \%$ & $100 \%$ \\
Bank Option 2a & $20 \%$ & $50 \%$ & $50 \%$ & $100 \%$ & $150 \%$ & $50 \%$ \\
Bank Option 2b & $20 \%$ & $20 \%$ & $20 \%$ & $50 \%$ & $150 \%$ & $20 \%$ \\
Corporate & AAA to AA- & A+ to A- & BBB+ to BBB- & BB+ to BB- & Below BB- & Unrated \\
& $20 \%$ & $50 \%$ & $100 \%$ & $100 \%$ & $150 \%$ & $100 \%$ \\
\hline
\end{tabular}

Option a: for claims of 3 months and more. Option b: for claims of less than 3 months.

Source: Basel Committee 2005

will also be subject to assessments under Basel II. Under the standardised approach, a sovereign debtor can be assigned to a risk weight of zero per cent for a debtor qualifying for triple A (like Singapore), which also corresponds to a capital charge of zero, up to a risk weight of 150 per cent for a debtor with an assessment of less than B-minus (like Argentina, Cameroon or Ecuador); this requires a minimum capital of twelve per cent with regard to the credit volume.

Table 4: Capital Requirements (Standardised Approach Basel II) in \% of Credit Volume

\begin{tabular}{lcccccc}
\hline & AAA to AA- & A+ to A- & BBB+ to BBB- & BB+ to B- & Below B- & Unrated \\
\hline Sovereign & 0 & 1.6 & 4 & 8 & 12 & 8 \\
Bank Option 1 & 1.6 & 4 & 8 & 8 & 12 & 8 \\
Bank Option 2a & 1.6 & 4 & 4 & 8 & 12 & 4 \\
Bank Option 2b & 1.6 & 1.6 & 1.6 & 4 & 12 & 1.6 \\
Corporate & AAA to AA- & A+ to A- & BBB + to BBB- & BB+ to BB- & Below BB- & Unrated \\
& 1.6 & 4 & 8 & 8 & 12 & 8 \\
\hline
\end{tabular}

Option a: for claims of 3 months and more. Option b: for claims of less than 3 months.

\section{Source: Basel Committee 2005}

With regard to claims on banks, Basel II offers two options. Under Option I, banks as debtors are not subject to an external assessment. Instead, their risk weight depends on the external assessment of the sovereign. Claims on banks under Option I are assigned one risk category less favourable than that which the sovereign of their host country is assigned. Under Option 2, banks themselves are assessed externally and claims on these banks are assigned to corresponding risk weights according to their borrower grade. In comparison to medium and long-term claims, short-term claims also receive preferential treatment, as was the case under the old accord (Option $2 \mathrm{a}$ versus $2 \mathrm{~b}$ ). The national supervisory authority - and not banks themselves - is to determine which option is to be applied for all banks under its jurisdiction. 
The definition of short-term was cut down from twelve months under Basel I to only three months in the new capital accord. This adjustment takes into account the experiences of the currency crises in the 1990s, especially the Asian and Argentinean ones. With widely liberalised capital markets, asset prices and exchange rates can change dramatically within twelve months. Although there was a remarkable shift from medium- and long-term to short-term lending before the outbreaks, banks from industrialised countries suffered in some cases considerable losses during the currency crises. Hence, in times of everyday volatile exchange rates, portfolio shifts have only three months' grace.

For all debtor categories, a borrower grade of »unrated « exists. While it is only a theoretical possibility for debtors seeking access to international capital markets, it will be mainly applied to the non-banking local private sector. The vast majority of corporates are not yet externally rated and, moreover, an external assessment of small and medium-sized enterprises, which make up the majority of the corporate sector, will be too expensive even in the future.

Summing up the main changes so far, it may be said that Basel II introduces more compulsory borrower grades, shows a wider spread of risk weights and therefore more differentiated capital requirements, and gives short-term claims on banks an even more favourable treatment than under the old accord.

\subsection{Different Approaches to Measuring Credit Risk}

With the exception of short-term claims on banks under Option 2 b, the assignment of banking book exposures to risk weights is based only on an assessment of the debtor. Basel II offers banks three different approaches to measuring credit risk. The simplest is the standardised approach, upon which both the remarks in the last section and the presentation in tables 3 and 4 are based. It is a modified version of the current standard. Banks using it fall back on external assessments of their debtors by traditional rating agencies or Export Credit Agencies. The thus determined borrower grades are associated with different risk weights, which are established under the new accord.

Alternatively, banks may use own risk estimation systems by introducing an internal ratings-based approach (IRB approach) to measure credit risk. These ratings must comprise at minimum data for the probability of default (PD), the loss given default (LGD), the exposure at default (EAD), and the maturity of the credit $(\mathrm{M})$. Banks which make use of the IRB foundation approach have to determine the PD, and are to obtain operational values for the other above-mentioned risk components from the national supervisory authority. Banks which apply the IRB advanced approach have to estimate the LGD, EAD and $\mathrm{M}$, in addition to the PD. Based on their own assessments of the debtors in terms of these risk components, claims will be assigned up to maximum of nine borrower grades for performing loans and two borrower grades for non-performing loans.

Before banks may use an IRB approach to calculate their capital ratio, they have to comply with certain minimum requirements and demonstrate compliance vis-à-vis the national supervisory authority. These minimum requirements include the stipulation that 
banks have at their disposal sufficient data with regard to the time horizon. Estimations of PD must be based on a minimum data observation period of five years, while in-house LGD and EAD estimates each require a time horizon of no less than seven years (Basel Committee 2005: paragraphs 463, 472, 478). The Basel Committee elaborates a total of twelve sections on the necessary minimum requirements. Among other things, banks have to demonstrate to their supervisory authority the accuracy of their quantitative estimates of risks, the consistency of their methodology, and the accuracy of the design of their rating systems, and they have to ensure that an independent audit of the rating system and the operation will take place. Apart from the above-mentioned data observation periods which can be verified relatively easy by supervisory authorities, the Basel Committee is less precise when it comes to putting other minimum requirements into practise. In its introductory remarks, the Basel Committee states,

"The overarching principle behind these requirements is that rating and risk estimation systems and processes provide for a meaningful assessment of borrower and transaction characteristics; a meaningful differentiation of risk; and reasonably accurate and consistent quantitative estimates of risk. Furthermore, the systems and processes must be consistent with internal use of these estimates. The Committee recognises that differences in markets, rating methodologies, banking products, and practices require banks and supervisors to customise their operational procedures. It is not the Committee's intention to dictate the form or operational detail of banks' risk management policies and practices. Each supervisor will develop detailed review procedures to ensure that banks' systems and controls are adequate to serve as the basis for the IRB approach." (Basel Committee 2005: paragraph 389)

In comparison with the current standard, the supervisory process will be considerably upgraded under Basel II: supervisors will not only have to fulfil more comprehensive and more complicated tasks for which they will require more specific know-how, they will also have a greater scope of intervention and more competence to come to decisions on a discretionary basis.

The Basel Committee has repeatedly stressed the flexibility with regard to different approaches to risk estimation that the new capital accord offers to banks. However, the flexibility refers only to the basic choice between the approaches offered. Apart from a short transition period, a bank may not in parallel use two or even three approaches to measure the credit risks of different claims and thus calculate its capital ratio. With regard to this item, Basel II rules out cherry-picking by banks which would otherwise have an incentive to minimise their capital cost by applying the approach with the least capital cost for each single exposure in their portfolios. Furthermore, while a transition from the standardised approach to an IRB approach is always possible - assuming compliance with minimum requirements - a downgrading from an IRB approach to the standardised approach is not intended by the Basel Committee.

However, a parallel use of different approaches by different banks in one country is not only possible, but highly probable. Internationally operating banks are supposed to 
introduce an IRB approach relatively quickly. ${ }^{3}$ In contrast, domestic banks of developing countries will need a prolonged time horizon to adjust themselves to the minimum requirements and apply for an IRB approach in comparison to their counterparts in industrialised countries.

"Several developing and transition countries' banks and regulators find the changes proposed idramatic and implementation by them sery complicated and demanding, if not impossible in the medium term^." (Griffith-Jones/Spratt 200I: 8)

Jonathan Ward, formerly at the Bank of England and the Financial Services Authority, where he was responsible for the reform of Basel I, puts it even more drastically:

"For developing countries, there is obligation without representation - a governance gap. The international regulatory framework is more nearly a colonial regime than official rhetoric admits. Developing countries cannot be expected to comply in good faith. The governance problem would matter less if the new accord were suitable for application in developing countries. It is not.« (Ward 2002: 57)

After widespread criticism by developing countries' monetary authorities ${ }^{4}$ the Basel Committee finally introduced the possibility to relax some of the minimum requirements for the duration of three years only beginning with the implementation date year-end 2006 . Subject to the discretion of national supervisors transitional arrangements within the new accord provide that banks need not to dispose of data with a longer time horizon than two years when they begin to introduce the IRB foundation approach (Basel Committee 2005: paragraphs 263-269; see also paragraphs 45-49). Those banks which will have started with the introduction of the IRB foundation approach at the end of this year are expected to dispose of a minimum data observation period of five years after the three years transition period (year-end 2006 to year-end 2009). Those banks which for several reasons are not able to introduce the IRB foundation approach already at year-end 2006 do not benefit from the transition arrangements. Besides the above-mentioned relaxation with regard to the time horizon, compliance with all other requirements is necessary; therefore we assume that the majority of developing countries' credit institutions will fall back on the standardised approach at first.

3 With regard to Euroland, all banks are already busily preparing themselves and streamlining their clients for a change to an IRB approach as quickly as possible. Their US counterparts are more sceptical. There, only internationally operating banks will rely on an IRB approach in the future, while US banks with a focus on the national market will stick to the standardised approach (The Federal Reserve Board 200I). Although Japan has committed itself to the new accord, the public should be concerned as to how Japan will ultimately implement it.

4 For comments and remarks by developing countries' monetary authorities see their detailed comments on $\mathrm{CP}_{2}$ and $\mathrm{CP}_{3}$ (http://www.bis.org/bcbs/cacomments.htm and http://www.bis.org/bcbs/ cp3comments.htm, respectively). 


\subsection{Introduction of an Operational Risk}

Basel II sets a capital requirement in terms of operational risk, in addition to credit risk and market risk which were already taken into consideration under the old accord. An operational risk is defined as the risk of loss from computer failures, poor documentation, corruption or fraud. Critical observers comment that the introduction of operational risk into the new accord lacks plausibility. "No convincing argument for the need of regulation in this area has yet been made." (Daníelsson et al. 200I: 3) Consideration of operational risk discloses discretionary scope to banks. The introduction of operational risk can be interpreted as the creation of a regulatory black box which allows banks even on the basis of assumed identical data and identical approaches not only to come to different results with regard to risk assessment, but also to take into account the banks own uncertainty about its rating.

Although it cannot be thoroughly assessed today whether banks will make use of the discretionary scope provided to them by the regulatory black box and whether they will build up a risk-adequate capital charge, doubt is called for. The European Central Bank (ECB) warns that

"the lack of incentives may lead to capital arbitrage and cherry-picking. Banks with higher risk profiles engaged in activities for which a higher beta ${ }^{5}$ is provided will be induced to opt for the basic indicator approach, whereas banks with lower risk profiles will be induced to opt for the standardised approach." (European Central Bank 2003: I2)

Therefore, it cannot be ruled out that banks under high pressure on the national or international market may present a lower operational risk than they actually anticipate. Especially the weakest banks in terms of financial solidity would obtain the opportunity to partially improve their liquidity and market position at the cost of sound risk management. If this interpretation is correct, the new accord would not only have failed to realise its own targets, but would have set counterproductive incentives.

With regard to an incorrect presentation of operational risk - or any other risk - it is highly problematical to place too much confidence in control of the market as a magic formula as does the Basel Committee. As long as losses from an (operational) risk have not been revealed - in other words, until the crisis is obvious to everybody - market agents cannot verify whether the capital charge of a bank to cover (operational) risk is really adequate. Furthermore, a bank which honestly reveals capital charges for above-average operational risks faces the danger not only of damage to its reputation but also of higher refinancing costs as a direct result of its bona fide transparency. Hence, either operational risk does not need to be covered by capital requirements at all, or regulations need to be revised again.

5 A beta factor is a capital factor with which an indicator for each business unit of a bank is multiplied to calculate the capital charge under the standardised approach. The beta factors are set by supervisors. For more details see Basel Committee 2005: Part 2, Section V. 


\section{Impacts of Basel II on International Lending to Developing Countries}

The possible differentiation of capital requirements according to borrower grades results in two effects. Firstly, Basel II induces a price effect on the international credit market. It sets incentives for an enhanced spread of interest rates according to the rating of borrowers which is to be the basis for the calculation of regulatory capital requirement in the future. The lower the rating of a borrower is assessed, the higher the necessary capital requirements will be. Low borrower grades and therefore increasing capital requirements will cause active interest rates to rise, while in the opposite case a proportionate interest rate decrease can only be expected under conditions of absolute competition. ${ }^{6}$ However, even if we assume imperfect competition and asymmetric information (Stiglitz/Weiss 198I), the existing interest rate spread between debtors, especially within one debtor category, will increase on the whole, and average credit costs for developing countries can be expected to rise.

Of course, interest rates differ already today. On the basis of specific criteria (e.g. debtor category, quality and volume of collateral, concept of investment project, term of payment, past experiences with a debtor), banks try to assess the risk of default by an individual debtor. The higher the risk of default assessed by a bank, the higher will be the interest rate the bank requests for lending. Even if two debtors require the same capital requirement under Basel I, interest rates for lending to them need not be identical, due to differences in the assessment of specific criteria. Hence, already today, actual interest rate spreads and not different capital requirements reflect the different risks of default by borrowers. The original function of minimum capital requirements consists in the accumulation of sufficient reserves to protect the bank itself in case of default by a debtor. A bank needs to fall back on its own reserves to maintain solvency, precisely when its lending is obviously not risk-sensitive. Hence, an increase in capital requirements does not make lending more risk-sensitive or even reduce the risk of default by the debtor, but reduces the risk of insolvency by banks in case of such default. Basel II can therefore be interpreted as a stateenforced protection measure for private banks, in case their lending turns out to be not, or not sufficiently, risk-sensitive.

For debtors in developing countries, the new accord implies consequences which are in some cases particularly harsh. Table 5 (on page I42) shows a comparison of minimum capital requirements for corporates under Basel I and Basel II, respectively. While under Basel I, minimum capital requirements are set independently of borrower grades for all corporate lending at a level of eight per cent of credit volume (see column 3 of table 5), minimum capital requirements under Basel II vary according to borrower grades. Using the standardised approach, minimum capital requirements start at I.6 per cent for borrower class A and peak at twelve per cent for classes B and triple-C (see column 4 of table 5 ). The spread in minimum capital requirements, which is already obvious under the standardised

6 See also Basel Committee (2003b), which also concludes an increased spread of interest rates. The Basel Committee follows the idea of a symmetrical interest rate adjustment which is therefore proportionate both upwards and downwards. 
approach, will even be enhanced when banks apply the IRB foundation approach to calculate their capital ratio. Capital requirements for lending under the IRB foundation approach start at I.I3 per cent for borrower class A and skyrocket to 47.04 per cent for Class C (see column 5 of table 5 ). ${ }^{7}$ Especially debtors with lower borrower grades will be affected by the progressive increase of capital requirements.

\section{Table s: Capital Requirements for Corporates in Comparison ${ }^{I}$ in \% of Credit Volume}

\begin{tabular}{lcccc}
\hline & PD $^{2}$ & Basel I & $\begin{array}{c}\text { Standardised } \\
\text { Approach }\end{array}$ & $\begin{array}{c}\text { IRB Foundation } \\
\text { Approach }\end{array}$ \\
\hline AAA & 0.03 & 8 & 1.6 & 1.13 \\
AA & 0.03 & 8 & 1.6 & 1.13 \\
A & 0.03 & 8 & 4 & 1.13 \\
BBB & 0.2 & 8 & 8 & 3.611 \\
BB & 1.4 & 8 & 8 & 12.35 \\
B & 6.6 & 8 & 12 & 30.96 \\
CCC & 15 & 8 & 12 & 47.04 \\
\hline
\end{tabular}

I In the agreed accord of July 2004, there is a weaker tendency on the marked convexity of the IRB approach, so that spreads in table 5 and figure I (see below) are slightly exaggerated.

2 Probability of default (PD), which is necessary to calculate the capital ratio with the IRB foundation approach, is given by the Bank of England (Jackson 200I).

Source: Jackson $200 I$

The estimated effects on the cost of lending to sovereigns of developing countries are similar to the effects on corporate lending. Under Basel II there will be a considerable increase in interest rate spreads and in credit costs for such debtors as well (Powell 200I). According to the standardised approach interest rates would slightly decrease for sovereigns of borrower grades of B BB and better, while on the basis of the IRB foundation approach, an improvement in credit costs can only be expected for sovereigns of developing countries classified A. There will be an increase of interest rates of up to 600 basis points for borrowers rated CCC or worse on the basis of the IRB foundation approach. Depending on which approach banks apply, sovereigns of developing countries with a borrower grade of B BB and lower will have to face an average increase in credit cost of at least 28 basis points, up to as much as 235 basis points (Powell 200I: 24). Even if declining capital requirements for high-rated borrowers are not proportionately reflected in interest rates, the spreads between high-rated and lowrated borrowers must increase. On the basis of recent foreign currency ratings (see table 6), a deterioration of international lending would currently occur in such countries as Brazil, Columbia, the Philippines or Vietnam. Hence, an accumulation of foreign debt by sovereigns of countries with lower ratings will be more limited under Basel II than it is already.

$7 \quad$ Within an IRB foundation approach probability of default (PD) defines assignments to borrower grades and a PD of 0.03 is the lowest value which is approved by the Basel Committee. 
Table 6: Examples of Foreign Currency Ratings of Developing Countries' Sovereigns, Including Transition Countries ${ }^{I}$

\begin{tabular}{|c|c|c|c|c|c|c|}
\hline AAA & AA & A & BBB & BB & B & C or lower \\
\hline & & & & & & Argentina \\
\hline & Bermuda & Bahamas & Bulgaria & Brazil & Benin & Belize \\
\hline & & Bahrain & & & Bolivia & \\
\hline & & Barbados & & & Burkina Faso & \\
\hline & & Botswana & & & & \\
\hline & & Chile & Croatia & Columbia & & Cameroon \\
\hline & & China & & Costa Rica & & \\
\hline & & & & & $\begin{array}{l}\text { Dominican } \\
\text { Republic }\end{array}$ & \\
\hline & & & & Egypt & & Ecuador \\
\hline & & & & El Salvador & & \\
\hline & & & & Guatemala & Georgia & \\
\hline & & & & & Ghana & \\
\hline & Hong Kong & & & & Grenada & \\
\hline & & Israel & & India & Indonesia & \\
\hline & & & & Jordan & Jamaica & \\
\hline & & Kuwait & Kazakhstan & & Lebanon & \\
\hline & & Malaysia & Mexico & Macedonia & Madagascar & \\
\hline & & & & Morocco & Mali & \\
\hline & & & Oman & & Mongolia & \\
\hline & & & & & Mozambique & \\
\hline & & & & Panama & Pakistan & \\
\hline & & & & Peru & $\begin{array}{c}\text { Papua New } \\
\text { Guinea }\end{array}$ & \\
\hline & & Qatar & & Philippines & Paraguay & \\
\hline & & & Romania & & & \\
\hline & & & $\begin{array}{l}\text { Russian } \\
\text { Federation }\end{array}$ & & & \\
\hline \multirow[t]{7}{*}{ Singapore } & & $\begin{array}{l}\text { Saudi } \\
\text { Arabia }\end{array}$ & $\begin{array}{l}\text { South } \\
\text { Africa }\end{array}$ & & Senegal & \\
\hline & & $\begin{array}{l}\text { South } \\
\text { Korea }\end{array}$ & & & Sri Lanka & \\
\hline & & & & & Surinam & \\
\hline & Taiwan & $\begin{array}{c}\text { Trinidad } \\
\text { and Tobago }\end{array}$ & Thailand & Turkey & & \\
\hline & & & Tunisia & & & \\
\hline & & & & Ukraine & Uruguay & \\
\hline & & & & Vietnam & Venezuela & \\
\hline
\end{tabular}

I Only ratings for the long-term perspective in foreign currency have been taken into consideration. 
Secondly, the differentiation of capital requirements according to borrower grades under Basel II results in a structural effect. The new accord sets incentives for a concentration of claims with high ratings in the portfolios of international banks. This structural effect is based on the assumption that banks calculate an identical mark-up as part of their interest rates. If interest rates reflect both the rating of the borrower and the credit risk of default, but the determination of the mark-up is independent of the borrower grade as such, then internationally operating banks will concentrate their lending on borrowers with high ratings. With a given equity, banks are able to realise a higher credit multiplier and can outlay a higher credit sum with claims of higher ratings than with claims of lower ratings. Assuming an identical mark-up on all claims, a concentration of claims with high ratings in the portfolios of banks implies higher profits in relation to equity. Furthermore, one can expect refinancing costs of those banks to be lower which have to show a portfolio of overwhelmingly high ratings, than would be the case for those banks with portfolios of only average quality. Hence, lower refinancing costs are also reflected in higher profits on equity. Thus, with a given equity and a concentration on claims with high ratings, the new accord would enable banks to realise a larger credit supply in absolute terms than under Basel I.

With the exception of Russia, all emerging market economies afflicted by a currency crisis had still been assigned to a high borrower grade one or two years prior to the outbreak of the crisis. Especially Southeast Asian countries had been lavishly praised for their ability to attract private net capital inflows due to an assumed successful catching-up process. To a lesser extent, a similar assessment was also applied to Argentina under Cavallo and Brazil under Cardoso. Under the logic of the new accord, the high rating of these countries before the crisis meant that internationally operating banks would have had an even higher incentive to extend their lending to these countries than they did in any case. Based on recent ratings (see table 6) Chile, South Korea and Malaysia would benefit from the new accord to the extent that declining minimum capital requirements would be reflected in decreasing interest rates and higher credit supply by internationally active banks. Hence, one cannot help but conclude that the assumed concentration on claims with high ratings in combination with slightly decreasing interest rates for borrower class A will not prevent currency crises in the future - on the contrary. Based on past experiences, ${ }^{8}$ and taking into consideration the pervasive incentives of Basel II, one could well expect acceleration and a deepening of currency crises in the future as a direct result of Basel II.

Another result of more risk-sensitive capital requirements consists in the credit crunch once a crisis is on the brink to break out. In figure I minimum capital requirements for outstanding loans to Argentina based on historical ratings by Standard \& Poor's are presented. During the crisis year 200 the ratings deteriorated in only six months from BBto CCC+. Under the old capital accord mandatory capital requirements had been stuck at eight per cent although credit institutions voluntarily increased their reserves in expectation of the default. According to Basel II minimum capital requirements would have to 
Figure I: Capital Requirements for Argentina During $200 \mathrm{I}$ in \% of Credit Volume

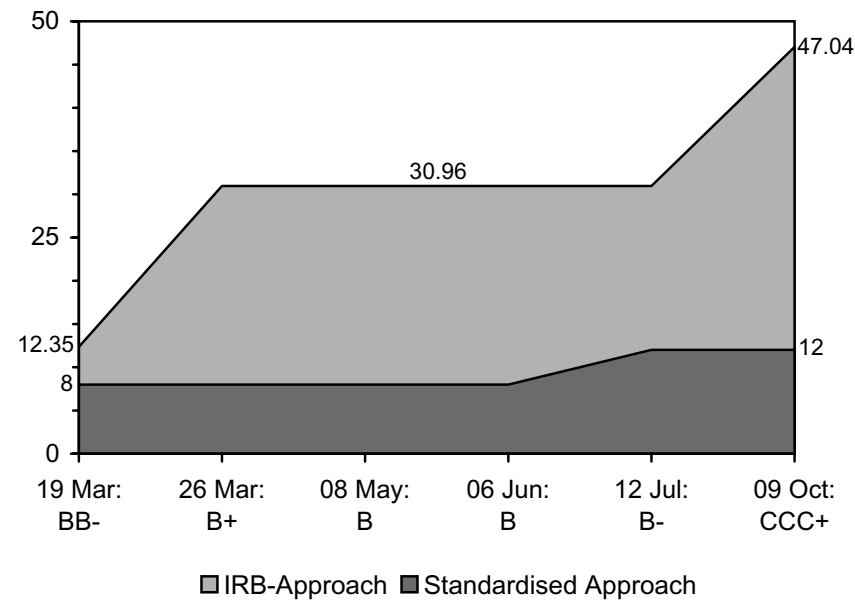

Source: Own presentation; probability of default is taken from Jackson (200I) and ratings are taken from Standard \& Poor's

be increased from eight per cent to twelve per cent under the standardised approach and jump from 12.35 per cent to 47.04 per cent under the IRB foundation approach which all internationally active banks will apply in the future. If banks are forced to increase their minimum capital requirements to such an extent only in a couple of months then it is not far from the mark to expect that the credit crunch will not only affect a country in crisis, in the example Argentina, but also debtors which are seeking to roll-over an already existing credit or trying to raise a new loan exactly during the time of the other country's crisis. Therefore, Basel II can be expected to enforce the typical boom-bust cycles and accelerate contagion.

\section{Impacts of Basel II on the Credit Markets of Developing Countries}

The parallel use of different approaches to measuring credit risk by different banks in developing countries for a prolonged time horizon is likely to have two effects. Firstly, as in international lending, Basel II will also have a structural effect, but this time with regard to the portfolios of banks operating in developing countries. Subsidiaries of internationally operating banks in developing countries will relatively quickly introduce an IRB approach and thereby concentrate their lending on claims with higher ratings, as in international lending. As pointed out in the above section, this cherry-picking behaviour of banks which use an IRB approach is induced by (expected) high profits in relation to equity. By contrast, banks in developing countries, which are acting on a local, regional or at maximum a national level, and are only able to use the standardised approach, will then have to serve 
the rest of the market, which means that they will accumulate more claims on borrowers with lower ratings and realise lower profits on a given equity. In its comment to the second consultative document, the ECB even expressed the warning that

"banks with a higher risk profile could have strong incentives to opt for the standardised approach, whereas banks with a lower risk profile may prefer the IRB approach. Thus, banks whose soundness would benefit most from more advanced risk management techniques could have the weakest incentives to develop them." (European Central Bank 2oorb: 2 f.)

Not only cherry-picking by international banks, but also active decisions of borrowers themselves would give rise to such a tendency. Corporates which are assigned to a borrower grade category of BB or lower are induced to establish credit relations with a bank which uses only the standardised approach, because minimum capital requirements and therefore credit costs tend to be lower than under an IRB approach (see table 5). Corporates which are unrated but do not assess themselves as BBB or better do have an even higher financial incentive to enter into credit relations with banks using the standardised approach. In that case, banks will apply a uniform minimum capital requirement of eight per cent to them while - depending on the actual rating - corporates would risk capital requirements of up to 47 per cent if they were assessed on the basis of an IRB approach.

"The main disadvantage of the standardised approach is that in many countries relatively few corporates are rated, which will mean that most exposures will be in an unrated category carrying $8 \%$ charge." (Jackson 200I: 59)

However, corporates which do assess themselves as $\mathrm{BBB}$ and better have an incentive to raise a loan at a bank which assesses on the basis of an IRB approach. In this way, higherrated corporates are able to benefit from lower interest rates even if banks only partially pass lower capital requirements on to them.

Therefore, the parallel use of standardised and IRB approaches by different banks in developing countries results in a negative selection with regard to the quality of the portfolio of those banks using the standardised approach. And these will not be subsidiaries of internationally operating banks, but rather domestic banks. Domestic banks of developing countries have no other option than to accumulate claims on borrowers with lower ratings. The argument of the ECB is turned around here: even if subsidiaries of internationally active banks and domestic banks of developing countries are able to present a portfolio of equal quality before Basel II is implemented, the latter will in any case be worse off after Basel II.

Secondly, Basel II induces a displacement effect of domestic banks of developing countries by internationally operating banks. Higher profits by subsidiaries of international banks improve competitiveness and - assuming hat these banks derive advantage from it increase their market domination of developing countries' credit markets. In contrast, lower profits for domestic banks in developing countries are reflected in a loss of competitiveness and an increased vulnerability to shocks and financial crises. The latter holds true 
especially when it is taken for granted that capital requirements based on an IRB approach are adequately risk-sensitive while capital requirements according to the standardised approach are either too high (for borrower classes A and triple-B) or too low (for the rest). Then domestic banks of developing countries, which have to use the standardised approach, would show a permanent under-coverage of risks from borrower grade BB and lower, which make up the overwhelming majority of their claims.

If all banks meet disclosure requirements according to Pillar Three of the new accord and if market participants are therefore able to assess banks adequately, then the displacement effect would even be intensified. The competitive disadvantage of domestic banks in developing countries would be increased because the refinancing costs of these banks would have to rise due to the low quality of their portfolios. By contrast, subsidiaries of internationally operating banks showing a portfolio of higher quality would have lower refinancing costs.

Assuming an identical mark-up on interest rates by both subsidiaries of internationally operating banks and domestic banks, the former will realise higher profits and possibly lower refinancing costs than the latter. This widening gap in rates of return between these groups competing for the local market will considerably strengthen the position of subsidiaries of internationally operating banks in developing countries.

Hence, as a result of the parallel use of standardised and IRB approaches in developing countries, one could expect domestic banks in developing countries to either specialise on niche production with weak financial solidity and sink into insignificance compared with the subsidiaries of internationally operating banks, or to completely vanish from their domestic markets through insolvency or by being taken over by subsidiaries of internationally active banks. Their only third alternative would be merger with one another, in order to combine know-how and capital and thus maintain competitiveness against the local subsidiaries of internationally operating banks. Therefore, apart from the niche production, all other options result in an increased concentration of ownership in the banking sector in developing countries. Moreover, a weakening of the domestic financial sector development and a change in property rights from domestic banks of developing countries to subsidiaries of internationally operating banks is therefore a more than probable result of Basel II.

\section{Conclusion}

The new capital accord is supposed to modify credit supply and portfolio choices by internationally operating banks in such a manner that their transactions no longer trigger off currency crises - a result which had been so much in evidence during the I990s. Basel II has the goal of quickly making bad banking - the systemic failure of the banking sector which generates excessive credit expansion and thus a bubble which will inevitably burst a thing of the past. However, a crisis prevention character can only be acknowledged for the new accord to the extent that it further restrains the access to international capital markets by low- and middle-income developing countries. Due to the price and struc- 
tural effects with regard to international lending, these countries will be confronted with higher interest rates and less credit supply on the international capital market. Therefore, a currency crisis set off by over-indebtedness and currency mismatch of stocks will be less probable for this group of countries for the simple reason that access to foreign cash will be strictly limited for them. Crisis prevention and risk-sensitive credit supply in times of Basel II translate to enforced withdrawal from certain market segments.

As these structural and price effects concerning international lending demonstrate, the new accord will set up incentives to increase credit supply and partially lower interest rates on the international capital markets for the group of highly-rated developing countries of the triple-B category and above, to which the majority of the crisis-afflicted countries belonged before their respective crises. During the boom phase, credit expansion to these countries would have been even higher under Basel II than it in fact was.

Hence, the result of the new accord would be to reinforce the familiar boom-bust cycles underlying international capital flows. This pro-cyclical tendency holds true not only for high-rated emerging market economies, but also for industrialised countries (see for example Deutsche Bundesbank 2003: 3 f., Danílsson et al. 200I: I5 f., European Central Bank 20ora: 66). But compared to industrialised countries emerging market economies often lack comprehensive institutional capacities and their domestic capital markets show considerable financial fragility, so that volatile capital inflows are more complicated to manage for them. Furthermore, following the "original sin« argument (Eichengreen et al. 2002, Hausmann 1999), net foreign debtor economies are objectively in a weaker position to cope with sudden U-turns of capital flows. In addition, Basel II would encourage herding behaviour by cutting down the short-term period from twelve to three months and thus raising the volatility of capital flows. Developing countries, and especially emerging market economies, thus face the risk that the inevitable credit crunch brought on by a crisis will be deepened and already high adjustment burdens increased. As the ECB stated: "The risk of adverse macroeconomic consequences would depend on the proportion of banks actually using the IRB approach." (European Central Bank 200Ia: 66) In fact, all internationally operating banks will use the IRB approach.

The prospective impact of Basel II on the credit markets in developing countries does not look any better. The use of different risk measurement approaches by different banks will result in high-quality portfolios for subsidiaries of internationally active banks and in low-quality portfolios for domestic banks in developing countries. This structural effect, together with the identified displacement effect due to competition disadvantages by banks using the standardised approach, is likely to expose domestic banks in developing countries not only to increased vulnerability to shocks and financial crisis, but also niche production. The new accord contains an inherent bias toward deepening financial dualism, and might therefore be a setback for financial sector development in developing countries. Thus, developing countries are all but the main beneficiaries of the new accord, and it should come as no surprise that their representatives have reacted to it with restraint or even open rejection. 


\section{References}

Basel Committee on Banking Supervision (1988): International Convergence of Capital Measurement and Capital Standards, Basel

Basel Committee on Banking Supervision (1994): Amendment to the 1988 Capital Accord Recognition of Collateral, Basel

Basel Committee on Banking Supervision (1995): Planned Supplement to the Capital Accord to Incorporate Market Risks, Basel

Basel Committee on Banking Supervision (1996): Overview of the Amendment to the Capital Accord to Incorporate Market Risks, Basel

Basel Committee on Banking Supervision (2003a): Consultative Document: The New Basel Capital Accord, Basel

Basel Committee on Banking Supervision (2003b): Quantitative Impact Study 3, Basel

Basel Committee on Banking Supervision (2005): International Convergence of Capital Measurement and Capital Standards: A Revised Framework, Basel

Daníelsson, Jón/Embrechts, Paul/Goodhart, Charles/Keating, Con/Muennich, Felix/Renault, Olivier/Shin, Hyun Song (200I): An Academic Response to Basel II, LSE Financial Markets Group and ESRC Research Centre, Special Paper, No. I30

Deutsche Bundesbank (2003): Statement by Edgar Meister, Member of the Board of Directors of the Deutsche Bundesbank, Interview in Connection With the Publication of the Third Basel Consultation Paper, May $6^{\text {th }} 2003$ [in German]

Eichengreen, Barry/Hausmann, Ricardo/Panizza, Ugo (2002): Original Sin: The Pain, the Mystery, and the Road to Redemption, http://www.iadb.org/res/publications/pubfiles/ pubS-I58.pdf

European Central Bank (200Ia): The New Capital Adequacy Regime - the Perspective of the ECB, in: Monthly Bulletin, May, pp. 6o-75

European Central Bank (20orb): The New Basel Capital Accord: Comments of the European Central Bank, May 2I $\mathrm{I}^{\text {st }}$ 200I (manuscript)

European Central Bank (2003): The New Basel Capital Accord: Reply of the European Central Bank to the Third Consultative Proposal (CP3), August 2003 (manuscript)

Griffith-Jones, Stephany/Spratt, Stephen (200I): Will the Proposed New Basel Capital Accord Have a Net Negative Effect on Developing Countries?, Institute of Development Studies (manuscript)

Hausmann, Ricardo (1999): Should There Be Five Currencies or One Hundred and Five?, in: Foreign Policy, in6, pp. 65-79

Jackson, Patricia (200I): Bank Capital Standards: The New Basel Accord, in: Bank of England, Quarterly Bulletin, Spring, pp. 55-63

Kindleberger, Charles P. (1996): Maniacs, Panics and Crashes: A History of Financial Crises, New York: John Wiley \& Sons

Krugman, Paul (1998a): Asia: What Went Wrong, http://www.pathfinder.com/fortune/1998/ 980302/fst8.html

Krugman, Paul (1998b): Will Asia Bounce Back?, http://web.mit.edu/krugman/www.suisse.html 
Metzger, Martina (200I): Of Magic Dragons and Other Strange Beasts: A Reassessment of the Latin American and Asian Crises, in: South African Journal of Economics, Vol. 69, No. 2, pp. I9I-2I7

Powell, Andrew (200I): A Capital Accord for Emerging Economies?, http://www.utdt.edu/ -apowell/Publications.htm

Secretariat of the Basel Committee on Banking Supervision (200I): The New Basel Capital Accord: An Explanatory Note, Basel

Stiglitz, Joseph E./Weiss, Andrew (198I): Credit Rationing in Markets with Imperfect Information, in: American Economic Review, Vol. 7I, No. 3, pp. 393-4IO

The Federal Reserve Board (200I): Remarks by Governor Laurence H. Meyer at the Bank Administration Institute's Conference on Treasury, Investment, ALM, and Risk Management, New York, New York, October $15^{\text {th }}$ 200I, http://www.federalreserve.gov/boarddocs/ speeches/200I/200IIoI5/default.htm

United Nations Centre on Transnational Corporations (199I): Transnational Banks and the International Debt Crisis, New York: United Nations

Ward, Jonathan (2002): Is Basel II Voluntary for Developing Countries?, in: Financial Regulator, Vol. 7, No. 3, pp. 5I-58 